\title{
Stakeholders' Compliance with Existing Construction Health and Safety Related Laws and Regulations in Ghana
}

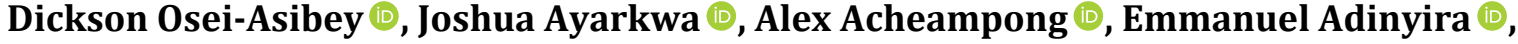 \\ Peter Amoah (1)
}

Department of Construction Technology and Management, Kwame Nkrumah University of Science and Technology (KNUST), Kumasi, Ghana

Email: dicksonoseiasibey@gmail.com, ayarkwajosh@yahoo.com, achielex@yahoo.com, rasadii@yahoo.com, amoahp@gmail.com

How to cite this paper: Osei-Asibey, D., Ayarkwa, J., Acheampong, A., Adinyira, E. and Amoah, P. (2021) Stakeholders' Compliance with Existing Construction Health and Safety Related Laws and Regulations in Ghana. Journal of Building Construction and Planning Research, 9, 138-159. https://doi.org/10.4236/jbcpr.2021.92010

Received: April 12, 2021

Accepted: June 1, 2021

Published: June 4, 2021

Copyright (C) 2021 by author(s) and Scientific Research Publishing Inc. This work is licensed under the Creative Commons Attribution International License (CC BY 4.0).

http://creativecommons.org/licenses/by/4.0/

\begin{abstract}
This paper explored stakeholders' compliance with existing laws and regulations related to construction health and safety (CHS) in the Ghanaian construction industry (GCI). Qualitative research approach was adopted for the data collection, using semi-structured interview guide. An in-depth face-to-face interview based on the grounded theory approach was conducted with actors who play important roles in ensuring health and safety at the construction site as well as key officers and professionals who are the major stakeholders in the GCI. Content analysis was adopted for the analysis of the qualitative data. The findings of the study show customary laws, bye laws, Labour Act, 2003 (Act 651), Local Governance Act, 2016 (Act 936) and the contract document as the key existing CHS related laws and regulations that the stakeholders comply with. The stakeholders also identified the following construction health and safety related regulations in the GCI which have low compliance rate: Factories, Shops and Offices Act, 1974 (Act 323), Environmental Protection Act, 1994 (Act 490), among others. The findings of the research contribute to knowledge of stakeholders' compliance with existing laws and regulations related to CHS, and underscore the need to ensure monitoring and enforce compliance in the GCI. The findings further identify areas for stakeholders to focus attention on ensuring good health and safety practices, and also expose critical training and education needs for stakeholders in the GCI. The findings provide valuable insights on stakeholders' compliance with laws and regulations related to CHS in Ghana, which may be applicable to other developing countries with similar construction industry.
\end{abstract}




\section{Keywords}

Laws, Regulations, Compliance, Construction Health and Safety, Ghana, Stakeholders

\section{Introduction}

Construction activities pose serious health and safety risks to construction professionals, construction workers, users of the constructed facility and the general public [1] [2] [3]. In this regard, laws and regulations have been developed to guide the management of health and safety in the construction industry. Construction Health and Safety (CHS) practices in the Ghanaian Construction Industry (GCI) mainly affect the construction processes. Given the serious health risks to construction professionals, construction workers, users of the constructed facility and the general public, health and safety have received a lot of attention in the construction industry for the past decade [1] [4]. In relation to Occupational Health and Safety (OHS), regulation, according to Eyiah et al. [5] refers to laws or rules that have their origin in the legislative arm of government which seeks to effectively manage OHS issues that negatively impact on persons whether employed or not. It must be emphasized that due to the complex nature of the construction industry, health and safety management studies from different perspectives have continued to emerge. However, not many studies have been conducted on health and safety from the legal perspective. The consequence of effective implementation and enforcement of OHS regulations is desirable behavioral changes in regulated organizations which will lead to desired intermediate outcomes and ultimately, reduced accident rates in regulated organizations or occupations covered by the regulation [5]. Thus, this study sought to assess the extent of compliance with existing legislations and regulations related to matters affecting CHS in the GCI.

\section{Literature Review}

\subsection{Stakeholders in Ghanaian Construction Industry}

The GCI is complex and involves several stakeholders for the completion of even small project. The key players in the GCI, as shown in Figure 1, include the clients, consultants, contractors, subcontractors, construction workers, suppliers and/or manufacturers of construction materials, equipment and tools, the regulatory institutions, community leaders, the local government, beneficiaries or users and in some instances the financiers, insurers or guarantors among others [6].

Stakeholders are defined as individuals and organizations who are actively involved in a project, or whose interests may be positively or negatively affected because of project execution or successful project completion [6] [7]. Donkoh and Aboagye-Nimo [8] and Osei-Asibey [6] have also studied stakeholders' roles 


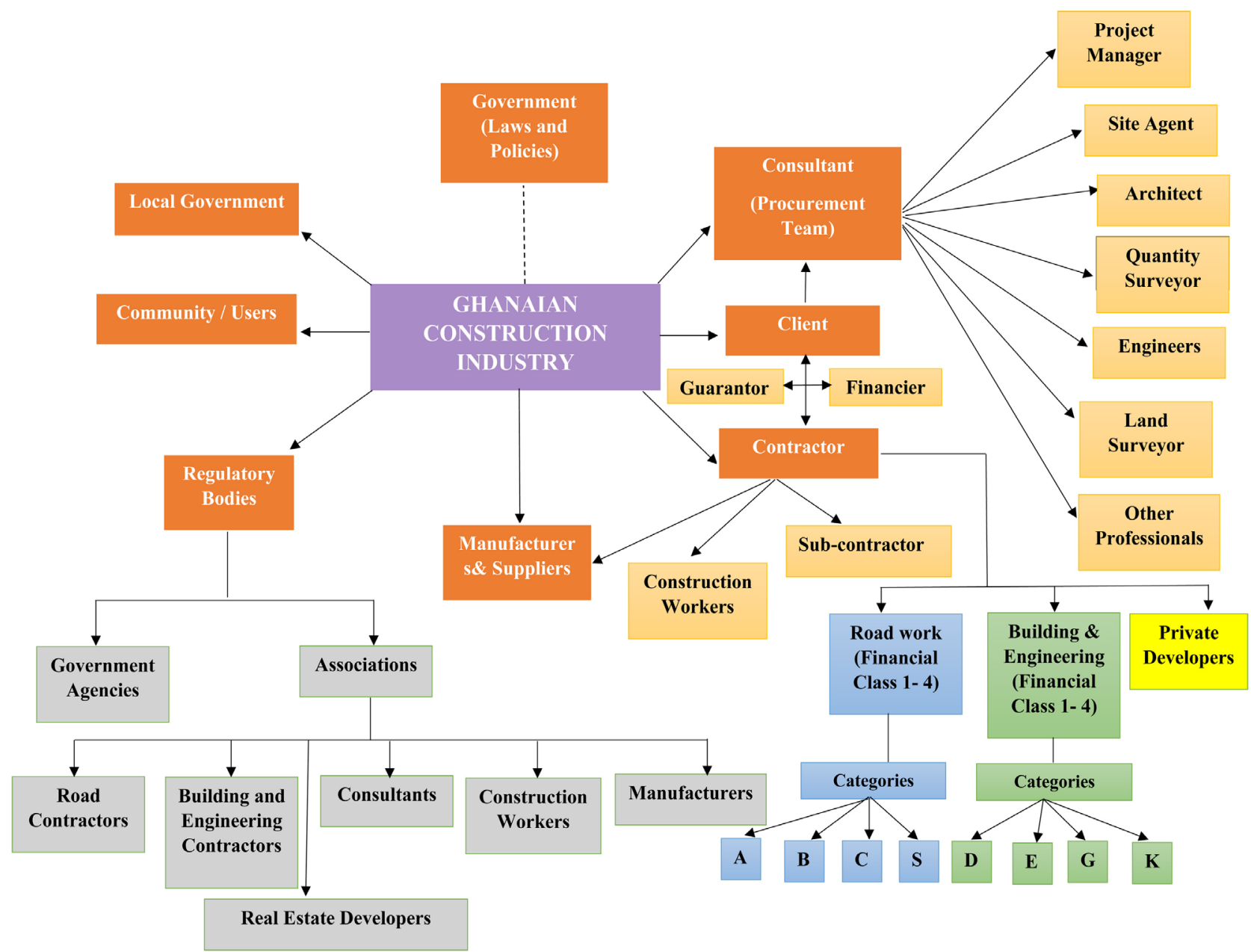

Figure 1. Stakeholders of the Ghanaian construction industry. Source: [6].

in improving construction safety in Ghana. Seven main stakeholders selected for the study are Consultants, Contractors, Construction Workers, Suppliers/Manufacturers, Local Government Officials, Community/Traditional Leaders and Regulatory Bodies.

\subsection{Construction Health and Safety Regulations in Ghana}

Governments all over the world make statutory provisions and regulations to ensure effective health and safety management in the construction industry. The regulations and statutory provisions for health and safety lay down the basic requirements for good employment practices and to some extent provide specific technical requirements for a particular work. In fact, they provide a technical basis from which a comprehensive safety policy is developed [9]. In the Ghanaian construction industry (GCI), Laryea and Sarfo [10] identified that lack of strong institutional framework for governing construction activities, poor enforcement of health and safety policies and procedures and the fact that the Ghanaian society does not place a high premium on health and safety of construction workers on site, are the primary reasons for the poor state of health and safety on 
Ghanaian construction sites. Construction work is carried out in constantly changing working environments, and this poses significant health and safety risks such as injuries, accidents, and loss of skilled workers [11]. The accidents and hazards that occur are very costly to the industry and all its stakeholders. According to Eyiah et al. [5], recurring factors that influence the effectiveness of OHS laws and regulations include: negligence and lack of priority for Occupational Health and Safety (OHS), lack of training, lack of funds for OHS, lack of investment in OHS management, lack of capacity of regulatory and supervisory institutions, lack of OHS education within construction firms, and OHS considered unimportant. Therefore, all stakeholders must endeavor to show full commitment to address most of the causes of accidents and hazards on site by complying with existing laws and legislations affecting the CHS matters. Few studies have been conducted in Ghana on stakeholders' compliance with existing regulations and legislation related to construction health and safety (CHS) matters from the legal perspective. Kheni et al. [12] stated that Ghana lacks unified occupational health and safety (OHS) legislation for regulating the activities of economic sectors including construction. Eyiah et al. [5] studied an assessment of OHS regulations in the Ghanaian construction industry and limited the study to only four legal provisions in Ghana: Factories, Offices and Shops Act, 1970 (Act 328); Workmen's Compensation Act, 1987 (PNDCL 187); Labour Act, 2003 (Act 651) and Ghana Health Service and Teaching Hospitals Act, 1996 (Act 526).

There is no written document on CHS laws in Ghana [13]. The legal structure on health and safety at the workplace in Ghana is an intricate one with several laws being applicable. These scattered health and safety provisions apply to all economic sectors including construction [12]. However, few health and safety provisions for construction activities specific are indicated in some of the Acts. In this regard, most of the health and safety provisions in the laws of Ghana applicable generally to industries, are also referred to the construction industry in Ghana. The major sources of laws in Ghana are, according to the 1992 Constitution of Republic of Ghana [14], 1) The Constitution, 2) Enactment made by or under the authority of the Parliament established by the Constitution, 3) Orders, Rules and Regulations made by any person of authority under a power conferred by the Constitution, 4) Existing laws, and 5) The Common Law. The CHS laws of Ghana may follow similar pattern of sources of law in Ghana. The laws regulating construction health and safety in Ghana are fragments of laws across the sources of laws in Ghana [15]. The health and safety regulations, however, place a responsibility on the employer (contractor) for the recruitment of competent personnel, provision of safe system of work, provision of safe workplace and provision of proper plant and equipment to workers under the common laws of Ghana [14] [16].

\subsection{Compliance with CHS Regulations}

Whilst literature suggests a gradual shift from regulatory regime to voluntary 
compliance in developed nations [17], developing countries are far behind this shift in paradigm in OHS management [5]. Voluntary compliance is minimal and much effort made in managing OHS is rather to comply first with contract provisions on health and safety and second an attempt at complying with OHS laws and regulations [5]. Ineffective enforcement by regulatory institutions results in lack of fear for punitive measures for flouting OHS regulations and laws and consequently low level of compliance with OHS laws and regulations [5]. Jaselskis et al. [18] have observed that a key factor moving proactive OHS management is fear of prosecution or punitive measures by maintaining an image of responsibility.

Many authors on OHS best practices have since documented the importance of top management commitment in improving health and safety performance [18] [19] [20] [21]. Construction managers believe that it is necessary and morally right to comply with OHS regulations as well as a genuine desire to improve staff morale and productivity is a contributory factor to proactive OHS management [22]. According to Eyiah et al. [5] management of construction companies tends to accord OHS low priority in comparison with profits. Compliance with OHS laws and regulations are invariably limited to compliance with contract provisions on OHS means there is little evidence to support proactive OHS behavior or management on the part of management [5]. Workers especially site managers and union representatives lacked empowerment on OHS issues and this could adversely affect compliance with OHS laws and regulations and achievement of safe and healthy construction sites. Fung et al. [23] observed that apart from the pressure of job security, other forms of social influences exist which may be brought to bear on workers and thus affect their psychological climate and consequently health and safety awareness level. The trust of regulatory institutions is to enforce OHS laws and ILO conventions relating to OHS, this arguably is associated with propensity to make OHS related improvements within regulated organizations [13] [24]. Implementing measures beyond those required in contract clauses in compliance with provisions OHS laws is seen as "going an extra mile" with little motivation either by punitive measures in OHS laws or optimizing the cost of safety [5].

\section{Research Methodology}

This study adopted the qualitative approach for the data collection. A qualitative approach is chosen to elicit existing knowledge in the form of questions and answers and the results are easily accessible to interpret [25]. Gay et al. [26] also emphasized that qualitative approach gives a large quantity of very in-depth information. This allows the researcher to gather more information by acting as an interviewer who forms part of the data collection process. An in-depth face-to-face interview based on the grounded theory approach was conducted with actors who play important role in ensuring health and safety on the construction site as well as key officers and professionals who are the major stakeholders in the 
Ghanaian construction industry (GCI). The major stakeholders considered in the study are Ghanaian Contractors (D1K1 and A1B1), Consultants (Architect, Quantity Surveyor and Civil Engineer), Suppliers/Manufacturers and Construction workers. The contractors in the class and categories D1K1 and A1B1 were selected because these are the large and experienced construction firms, likely to make the effort to comply with health and safety requirements. The suppliers were included because they are expected to supply equipment and tool in good working conditions, and provide adequate and right information regarding the usage of materials and equipment to ensure safety on site. The other actors considered in this study are: Traditional Authorities (Chiefs and Elders), Regulatory Bodies (Environmental Protection Agency (EPA), Factories Inspectorate Department, Public Procurement Authority (PPA), Ghana Police Service, Labour Department, and Ghana National Fire Service), and Local Government Authorities. The selection of interview participants was based on purposive sampling technique.

Participants for the interview were seven each of the stakeholders. The seven stakeholder groups were selected due to their relevance to the issue under study in the Construction Industry. Data saturation principle was used in limiting the number of each stakeholder group to 7. Data saturation used in this sense refers to a point at which further interviews yielded no new or additional insights regarding the research questions posed [5] [27] [28]. This means that the number of interviews progressed up to a point where no additional/new insights to the research objectives were obtained from the study participants [5]. Since the Contractor group is considered as the fulcrum around which all other stakeholders revolve, the saturation point for contractors of 7 was used to select the number of participants from the other stakeholders.

This sampling approach was adopted to have in-depth information on the phenomenon under study. This was adopted also to ensure that persons familiar with the principles and management of construction health and safety (CHS) were interviewed for the purpose. The purposive sampling technique was used for selecting the interviewees from all the categories of participants. In purposively selecting participants, the criteria outlined in Table 1 were used. In all, forty-nine (49) interviewees participated in the interview.

The interviewees were selected from the Greater Accra and Ashanti regions in Ghana. These are the two biggest regions in Ghana where most of the biggest infrastructure development projects are located, and therefore home to majority of the $\mathrm{D} 1 \mathrm{~K} 1$ and $\mathrm{A} 1 \mathrm{~B} 1$ contractors as well as the major suppliers/manufacturers and reputable consultants. All the regulatory bodies are located in these two regions. The local Government Authorities and the traditional authorities are located across all the regions including the selected two regions. The opinions gathered from these regions can therefore be fairly generalized for the whole country.

The interviewees were taken through a well-focused interview, using semi-structured open-ended questions. The interviewees responded to questions 
Table 1. Criteria for group participants in interview.

\begin{tabular}{|c|c|c|}
\hline $\begin{array}{l}\text { Group } \\
\text { Participants }\end{array}$ & Number & Criteria \\
\hline $\begin{array}{l}\text { Contractors } \\
(\mathrm{D} 1 \mathrm{~K} 1 ; \\
\text { A1B1) }\end{array}$ & 7 & $\begin{array}{l}\text { The professionals working with the D1K1 (General Building and } \\
\text { Civil Engineering category in Financial Class 1) or A1B1 (Road } \\
\text { and Concrete Structures Construction category in Financial Class } \\
\text { 1). The interviewees belong to the professional bodies and } \\
\text { construction associations of their status. They have experience } \\
\text { between } 12 \text { and } 22 \text { years in the construction industry. } \\
\text { The contractor must have engaged in construction } \\
\text { projects in two or more regions in Ghana. }\end{array}$ \\
\hline Consultants & 7 & $\begin{array}{l}\text { The consultants must have had adequate knowledge and been } \\
\text { trained in health and safety management. The Consultants } \\
\text { belong to the various professional bodies which are well } \\
\text { recognized in the GCI, personnel of senior level and authority } \\
\text { in their various Consulting firms with at least 5years experience } \\
\text { in their various field of expertise. }\end{array}$ \\
\hline $\begin{array}{l}\text { Suppliers/ } \\
\text { Manufacturer }\end{array}$ & 7 & $\begin{array}{l}\text { The supplier/manufacturer must be a dealer of the major } \\
\text { construction materials such as cement, reinforcement rods, } \\
\text { roofing sheet and tiles. All the supplier/manufacturer interviewees } \\
\text { must have at least two depots across the country and have been } \\
\text { in business for at least 5years, to indicate that respondents have } \\
\text { enough experience in the manufacturing and supply of } \\
\text { construction materials in Ghana. }\end{array}$ \\
\hline $\begin{array}{l}\text { Construction } \\
\text { Workers }\end{array}$ & 7 & $\begin{array}{l}\text { The worker must have worked with a D1K1 or A1B1 classes of } \\
\text { contractors in Ghana for a minimum of five (5) years. The selected } \\
\text { construction workers must be representatives of the most active } \\
\text { trades within the GCI, masonry, carpentry, steel works etc. }\end{array}$ \\
\hline $\begin{array}{l}\text { Traditional } \\
\text { Authorities }\end{array}$ & 7 & $\begin{array}{l}\text { The traditional leader/authority must be in a community with } \\
\text { ongoing construction project. }\end{array}$ \\
\hline $\begin{array}{l}\text { Local } \\
\text { Government } \\
\text { Officers }\end{array}$ & 7 & $\begin{array}{l}\text { Local Government officers must also be in a District with ongoing } \\
\text { large-scale construction project. The officers are in the } \\
\text { management class such as Chief Executive, Coordinating } \\
\text { Director, Planning Officer, Budget Analyst, Engineer etc. }\end{array}$ \\
\hline $\begin{array}{l}\text { Staff of Other } \\
\text { Regulatory } \\
\text { Bodies }\end{array}$ & 7 & $\begin{array}{l}\text { Staff of Factories Inspectorate Department, Labour Department, } \\
\text { Environmental Protection Agency (EPA), Police Service, Ghana } \\
\text { National Fire Service, and Public Procurement Authority (PPA) } \\
\text { identified to be senior management staff in the organization. }\end{array}$ \\
\hline Total & 49 & \\
\hline
\end{tabular}

in relation to their compliance with the existing laws and regulations on CHS in the Ghanaian construction industry. They were asked to specifically mention which of the existing construction health and safety laws and regulations they comply with in the course of their operations. The interview guide provided interviewees the opportunity to elaborate more on the subject matter being discussed. Prior to the fixing of interview date, the open-ended questions were sent 
to all interviewees. To allow for convenience of the interviewees, the interview session took place in the offices of the interviewees, except for certain interviewees without offices where the interviews took place in the comfort of their residence or other convenient places.

On the average, the interview section took between 45 and 60 minutes per participant. All but five interviewees were recorded by means of an audio recorder. The five interviewees who were not recorded, indicated that they would not be allowed to be recorded by means of an audio recorder. Their responses were then directly hand-written and later confirmed by them. The audio recordings of majority of the interviews were done to ensure the accuracy of notes taken from the field and also to provide more rendition of an interview.

The qualitative data from the face-to-face interviews were analyzed using the content analysis technique. Content analysis seeks to identify the main facets of a set of data by counting the number of times an activity occurs [26]. The first step in content analysis is the identification of the data or material to be analyzed. The second step identified the content technique to employ. The audio recordings were then transcribed by creating a verbatim text of each interview. The interview transcripts were then analyzed by re-reading the transcripts to identify the themes that emerged from the interviewees' answers. The themes were summarized in tables and the number of times it is mentioned by interviewees was tallied. The transcripts were sent to the interviewees for their confirmation. Comments and corrections were then incorporated into the final transcript.

\section{Results and Discussion}

\subsection{Compliance with Existing Construction Health and Safety (CHS) Related Laws and Regulations in the Ghanaian Construction Industry (GCI)}

The study assessed stakeholders' compliance with existing construction health and safety related laws and regulations in the GCI by asking them to specifically mention which of the existing construction health and safety laws and regulations they comply with in the course of their operations. The results obtained from the seven stakeholder groups and presented in Table 2, are considered and discussed. The results revealed twelve (12) existing CHS related laws and regulations that the stakeholders complied with as: Contract Documents; Labour Act, 2003 (Act 651); Factories, Shops and Offices Act, 1970 (Act 328) as amended; National Building Regulations, 1996 (L.I.1630); Workmen's Compensation Act, 1987 (PNDCL 187); Public Procurement Act, 2003 (Act 663) as amended by Public Procurement Amendment Act, 2016 (Act 914); Customary Law; Bye-Laws of relevant MMDA; Public Order Act; Environmental Protection Act, 1994 (Act 490); Fire Precaution (Premises) Regulation, 2003 (L.I. 1724) as amended by Fire Precautions (Premises) Amendments Regulation, 2016 (L.I. 2249); and Local Governance Act, 2016 (Act 936), presented in Table 2. 
Table 2. Compliance with existing health and safety law and regulations.

\begin{tabular}{|c|c|c|c|c|c|c|c|c|c|c|}
\hline CODE & Regulations & $\begin{array}{c}\text { Contractors } \\
\text { (7No) } \\
\text { (CR1-CR7) }\end{array}$ & $\begin{array}{l}\text { Consultants } \\
\text { (7No) } \\
\text { (CT1-CT7) }\end{array}$ & $\begin{array}{l}\text { Workers } \\
\text { (7No) } \\
\text { (W1-W7) }\end{array}$ & $\begin{array}{l}\text { Suppliers } \\
\text { (7no) } \\
\text { (S1-S7) }\end{array}$ & $\begin{array}{c}\text { Local } \\
\text { Government } \\
(7 n o) \\
\text { (LG1-LG7) }\end{array}$ & $\begin{array}{l}\text { Traditional } \\
\text { Authority } \\
\text { (7no) } \\
\text { (T1-T7) }\end{array}$ & $\begin{array}{l}\text { Regulatory } \\
\text { Bodies } \\
(7 n o) \\
\text { (R1-R7) }\end{array}$ & $\begin{array}{c}\text { Total } \\
(49)\end{array}$ & Ranking \\
\hline R1 & $\begin{array}{l}\text { Contract } \\
\text { Document }\end{array}$ & 7 & 7 & - & 7 & - & - & - & 21 & 2 \\
\hline R2 & Labour Act & 5 & - & 1 & - & - & - & 2 & 8 & 3 \\
\hline R3 & $\begin{array}{l}\text { Factories, Offices } \\
\text { \& Shops Act }\end{array}$ & 4 & - & - & - & - & - & 2 & 6 & 6 \\
\hline R4 & $\begin{array}{l}\text { National Building } \\
\text { Regulations }\end{array}$ & 3 & - & - & - & - & - & - & 3 & 7 \\
\hline R5 & $\begin{array}{l}\text { Workmen's } \\
\text { Compensation }\end{array}$ & 2 & - & - & - & - & - & 1 & 3 & 7 \\
\hline R6 & Customary Law & - & - & - & - & - & 7 & - & 7 & 4 \\
\hline R7 & Bye-Laws & 5 & - & 7 & - & 3 & 7 & - & 22 & 1 \\
\hline R8 & Public Order Act & - & - & - & - & - & - & 1 & 1 & 9 \\
\hline R9 & $\begin{array}{l}\text { Environmental } \\
\text { Protection Act }\end{array}$ & - & - & - & - & - & - & 1 & 1 & 9 \\
\hline R10 & $\begin{array}{l}\text { Public } \\
\text { Procurement Act }\end{array}$ & - & - & - & - & - & - & 1 & 1 & 9 \\
\hline R11 & Fire Regulation & - & - & - & - & - & - & 1 & 1 & 9 \\
\hline \multirow[t]{2}{*}{ R12 } & $\begin{array}{l}\text { Local } \\
\text { Governance Act }\end{array}$ & - & - & - & - & 7 & - & - & 7 & 4 \\
\hline & $\begin{array}{l}\text { TOTAL No. of } \\
\text { Regulations }\end{array}$ & 6 & 1 & 2 & 1 & 2 & 2 & 6 & 12 & \\
\hline
\end{tabular}

\subsection{Identifying Different Stakeholders' Compliance with Existing Construction Health and Safety (CHS) Related Laws and Regulations}

All the seven different stakeholders were interviewed on their compliance with existing CHS related laws and regulations in the GCI. The results of the interview are considered in this section.

\subsubsection{Contractors' Compliance with Existing CHS Related Laws and Regulations}

Contract Document was mentioned by all the seven contractor interviewees as the CHS related regulation most complied with. The Contract Document is a binding document in a contract and its provisions are adhered to by all parties. Commenting on this, CR1 stated,

"Contract Document usually contains provisions to ensure health and safety. It is a binding document and must be complied with whether is possible or not".

Labour Act, 2003 (Act 651) and Factories, Shops and Offices Act, 1970 (Act 
328) were also mentioned five and four times respectively by contractor interviewees as CHS related regulation complied with.

It was mentioned that,

"Labour Act and Factories, Offices and Shops Act form the major health and safety regulations for us, so we try to comply with some of the provisions" (CR3).

The Collective Bargaining Agreement (CBA) is one of the bye-laws that the contractor interviewees complied with during the construction stage of the work. It sets out the relationship between the Contractor and the construction workers in an agreement. It is also a binding document adhered to by both parties. It was lamented that,

"The CBA outline all that obligations of the contractor to ensure the welfare of the workers and therefore we often result to the CBA in ensuring CHS' (CR6).

The other laws and regulations the contractor interviewees complied with are National Building Regulations, 1996 (L.I. 1630) and Workmen's Compensation Act, 1987 (PNDCL 187), but these were mentioned by only 3 and 2 participants respectively. It appears the contractors comply more with the provisions in the Contract document than the other existing laws and regulations identified in this study. Apart from Contract documents, contractors should also focus their attention on the other laws and regulations to ensure good health and safety practices in the GCI.

\section{1) Contract Documents}

The documents forming the contract which include the Agreement, Letter of Acceptance, Contractor's Tender, Contract Data, Conditions of Contract, Specifications, Drawings, Bill of Quantities or Activity of schedule in lump sum contract, and any other document listed in the contract data as forming part of the contract, together form what is referred to as Contract Document (Conditions of contract of Public Procurement Authority of Ghana). It is a binding document between the contractor and the client recognized in law. It is therefore not surprising that it is a regulation that the contractors upheld for ensuring CHS at construction site. The CHS provisions and requirements in the contract document may also be found in some of the various documents. Where the Contractor's Tender contains health and safety policy or plan, the health and safety policy and/or plan may provide provisions and requirements for ensuring health and safety at the construction site. The preliminary or general items of the Bill of Quantities may set out some health and safety requirements including welfare facilities at the construction site. The specification also may offer procedures and measures for executing the works to avoid accidents and hazards at site. The condition of contract provides under clause 19 that the contractor shall be responsible for the safety of all activities on the site. It, however, fail to spell out in detailed the specific activities and measures to be taken and the penalty in default. It is, however, the responsibility of the contractor to abide by all provisions and requirements in the contract documents to ensure CHS at site. 


\section{2) The Labour Act, 2003 (Act 651)}

The Labour Act, 2003 (Act 651), which is also known as the Labour Law, is an Act of Parliament of the Republic of Ghana enacted in 2003. This Act which seeks to regulate the operations of the Ghanaian labor force also makes provisions for health and safety of workers at workplaces. It is also one of the major laws affecting health and safety applicable in the construction industry. The provisions under the heading Occupational Health, Safety and Environment of the Act are the major part which focuses on health and safety conditions at workplaces. It must be emphasized that other parts of the Act also address certain safety issues but not as detailed as this part of the Act. It consists of four major sections viz.; Section 118, 119, 120 and 121. Section 118 of the Act makes provisions for the general health and safety conditions expected at workplaces, imposes certain duties on both employers and employees in ensuring health and safety conditions at workplace. For instance, section 118 (2a) emphasizes that employers must make provisions and maintain a plant and safe system of work at the workplace without risk to health. Other obligations of the employer include preventing accidents and hazards and injury associated with a particular work, providing adequate and clean drinking water at workplace, as well as ensuring a separate and suitable toilet and other social amenities at the workplace.

The provisions under the heading Occupational Health, Safety and Environment of the Act are the major part which focuses on health and safety conditions at workplaces. It must be emphasized that other parts of the Act also address certain safety issues but not as detailed as this part of the Act. It consists of four major sections viz; Section 118, 119, 120 and 121. Section 118 of the Act makes provisions for the general health and safety conditions expected at workplaces, imposes certain duties on both employers and employees in ensuring health and safety conditions at workplace. For instance, section 118 (2a) emphasizes that employers must make provisions and maintain a plant and safe system of work at the workplace without risk to health. Other obligations of the employer include preventing accidents and hazards and injury associated with a particular work, providing adequate and clean drinking water at workplace, as well as ensuring a separate and suitable toilet and other social amenities at the workplace. Again, employers are obliged by this Act to provide necessary information, instructions and training to workers with regards to their age and literacy level. This is intended to provide to the worker knowledge and education on issues like health and safety. Moreover, this Act imposes certain responsibilities on employees or workers at the workplace. Section 118 (3) stipulates that every worker must use any safety appliances, fire-fighting equipment and preventive and protective equipment (PPE) made available by the employer. In this regard, should the employee fail to use the (PPE's) made available by the employer, the employer shall not be liable for any injury suffered by the worker (Section 118 (4)), especially, when the employee has been educated and trained on the use of such equipment. However, it is an offense if an employer fails to make the ne- 
cessary provisions for health and safety at the workplace (Section 118 (5)). Section 119 emphasises on how exposure to imminent hazards could be managed at workplace. It indicates that workers should report any situation that poses serious danger to their lives and health. Furthermore, this section provides that under no circumstances should the employment of a worker be terminated or any remuneration of the worker be withheld if the worker removes him/herself from a situation of which the worker believes is dangerous to his life or health. Section 120 makes provision for employers to report any occupational accidents and hazards and diseases to an appropriate government agency. In fact, it stipulates that reports must be made not later than 7 days from the date of its occurrence. The final section (section 121) on health and safety at the workplace allows the Minister to make regulations to provide specific measures which should be undertaken by employers to ensure health and safety at workplace. As indicated earlier, there are other general duties of employers in the Labour Act which addresses health and safety issues but those are not directly provided. It is, however, mandatory for the Contractors (employers) to ensure that these provisions are observed at the construction sites and offices where the employees may be working.

\section{3) Factories, Offices and Shops Act, 1970 (Act 328)}

The Factories, Offices and Shops Act, 1970 (Act 328) comprise of 49 sections of health and safety provisions. The other headings provide description of factories, offices and shops as well as offences and legal proceedings. Section 57 establishes the sections within the Act which are applicable to building operations and engineering construction works. Section 57 stipulates application of the law to any building operations and activities of engineering construction works. Provisions of section 57 are applicable to public and commercial building, civil engineering and road works. It provides for contractors to inform District Inspectors of the commencement of the work with detailed particulars of the project, details of any mechanical power to be used and other particulars, details and the nature of works to be carried out to District Inspectors. The Minister is obliged to make regulations to provide more health and safety provisions, scaffolding, the lifting machinery, excavations, site supervision, provision of welfare facilities and the imposition of duties on stakeholders of construction or engineering projects. Every factory (Construction Sites/workplace) must have a general register in a prescribed form, and attached to it should be the prescribed particulars of every accident and hazard and case of occupational diseases which occurs at the factory (workplace). Accidents and hazards at the workplace are to be properly recorded and investigated, and occupiers (contractors) of the factory (workplace) to submit to an Inspector, the extracts from the general register. This provision actually enables proper monitoring of management of health and safety by Inspectors, and imposes health and safety obligations on the employer (occupier); prevent accidents and hazards in building operation and constructions works; establishes the notification of an accident and hazards at the 
workplace, indicates any form of accidents and hazards at the workplace and send in a written notice to the District Inspector. When any person is injured or killed the District Inspector must be notified in writing. The District Inspector must focus on the notification of dangerous occurrences and industrial diseases and ensure a better monitoring system of accidents and hazards. The District Inspector must place emphasis on the availability of sanitary facilities accessible to all persons employed and more importantly where both sexes are employed separate sanitary facilities should be provided, the provision of adequate wholesome drinking water at the workplace (Construction site); the provision of protective clothing and appliances, such as overalls, safety boots, goggles and head coverings to workers working under excessive exposure to wet, injurious and offensive substances. Again, emphasis is placed on the reduction of noise at workplace (construction site) through the adoption of appropriate and practicable measures by employers, workers should not be allowed to carry load which is likely to cause injury, and the availability of first aid box or cupboard during working hours. The stakeholders are entreated to comply with these provisions.

The Minister (Minister of Employment) may require conditions at a workplace arranged for medical supervisions of persons employed at the workplace (construction site), provision for health and welfare regulations covering health and safety issues such as noise control, vibrations, ventilations, washing facilities, lighting etc. Constructors are to make provision of safety measures in case of fire and proper safe means of access respectively; the safety measures to ensure the safe construction of floors, passage and stairs in buildings and at the workplace; a substantial handrail to every staircase in a building as well as openings in floors; all ladders must be properly constructed and maintained; provisions for training and supervision for any person employed to operate a machine; provision of competent and experienced persons to operate machines or process on working site; the regular cleaning of the parts of machine being used; no woman or young person should be allowed to clean a machine part or a prime mover.

Other provisions include the provision for the fencing of dangerous machinery, safeguard of transmission machinery and the construction and maintenance of the machine fencing respectively; focuses on how heavy-duty machines and equipment such as cranes, hoist, lifts, steam boilers among others could be used in a safety manner without causing injury to operators. Provisions are made to deal with liability for contravention of the Act by an occupier, owner or a person which provision of a regulation expressly imposes a duty on, actual offender, and owner of machine. Although the Act was enacted in 1970 amendments had been made by the Factories, Offices and Shops (Amendment) Law, 1983 and 1991 (PNDCL 66 and 275 respectively). There have been no new Regulations neither have the 1959 and 1960 regulations been modified to address modern trends in the Construction Industry. The existing Regulations are moreover not adequate to cover the Act especially the Building operations and 
works of engineering construction provisions.

\section{4) Workmen's Compensation Law, 1987 (PNDCL 187)}

The PNDCL 187 emphasis on the provision of compensations to injured persons at workplace as a consolation to workers who suffer injuries at the workplace. In fact, it imposes duties on employers to compensate any injured person at the workplace. This law consists of 39 sections with detailed sub sections focusing on compensations to workers due to death, cases of permanent total incapacity, partial incapacity, temporary incapacity and disfiguring injuries; the agreement calculation and sharing of compensation including any medical examinations and treatment such that in case of any report of injury of a worker the employer must provide free medical attention to the worker (Section 14); the court proceedings for claiming compensations and the medical fees that should be paid in case of any injuries to workers (Section 28 and 29).

\subsubsection{Consultants' Compliance with Existing CHS Related Laws and Regulations}

The results in Table 2 show that in the opinion of the Consultant interviewees, the only regulation and law that guide consultants in the performance of their duties to ensure health and safety on site is the Contract Documents. CR5 stated that:

"Our laws and regulations are what is contained in the Contract Document. We ensure that what is contained in the contract document is adhered to by the contractor. In this way we prevent any accident and hazards that would have otherwise occurred."

The opinion of the consultant interviewees shows complete ignorance of the existence of CHS related laws and regulations for use by Consultants. According to the National Building Regulation, 1996 (L.I. 1630) of Ghana [29], design of buildings is to meet the specifications provided therein. The Public Procurement Act, 2003 (Act 663) as amended by Public Procurement Amendment Act 2016 (Act 914) of Ghana [30] also provides regulations for the procurement of works, goods and services in Ghana. These are all laws and regulations that the consultants are obliged to comply with. The show of ignorance of the Consultants of existing laws and regulations on CHS for their compliance may be attributed to the lack of unified occupational health and safety (OHS) legislations for regulating the activities of the construction industry, in agreement with Kheni et al. [12].

\subsubsection{Construction Workers' Compliance with Existing Construction Health and Safety (CHS) Related Laws and Regulations}

Collective Bargaining Agreement is a bye-law which provides the rules regulating the relation between the employer and the employee in Ghana. The bye-law (i.e. Collective Bargaining Agreement (CBA)) is the regulation most complied with by the seven construction worker interviewees. One worker, however, mentioned the Labour Act, 2003 (Act 651) in addition to the CBA. CW6 stated that,

" $C B A$ provides adequate measures to ensure health and safety of workers. It 
provides for the welfare of all workers in Ghana. Therefore, as construction workers forms part of the Workers Union, we are obliged to comply with the $C B A^{\prime \prime}$.

According to the Workmen's Compensation Act, 1987 (PNDCL 187) of Ghana [31], employers are to provide compensation to workers. It is another major existing law with health and safety provisions for workers at the workplace which they do not seem to comply with. There is the need for training of workers on CHS related laws and regulations to ensure compliance.

\subsubsection{Local Government Officers' Compliance with Existing Construction Health and Safety (CHS) Related Laws and Regulations}

Local Government Official Interviewees indicated that the major existing CHS related laws and regulations they complied with are the Local Governance Act, 2016 (Act 936) and the bye-laws of the District Assemblies. LG2 stated that,

"Sections of Act 936 oblige district officers to ensure safety within the District Assemblies. We provide permits and visit constructions sites to perform our mandate. Our challenge is that we are not able to visit sites as often as we ought to, but we are doing our best".

LG7 also mentioned that,

"The Assembly has come out with bye-laws to ensure that the construction activities are done in safe and sound environment, for example, sand and other materials to site are supposed to be covered with tarpaulin by the sand supplier. Our mandate is to ensure that such bye laws are complied with. The bye laws come with sanctions and fines. It is a source of income to the Assemblies and therefore we have task force that are going around the communities to enforce the bye-laws".

It appears that logistical challenges impede the ability of Local Government Officers to comply with existing laws and regulations under their jurisdiction. Resourcing the local authority could go a long way to ensure monitoring and enforce compliance with existing laws and regulations in the GCI, since ineffective enforcement by regulatory institutions results in lack of fear for punitive measures for flouting CHS regulations and laws, and consequently low level of compliance [5].

\section{Local Governance Act, 2016 (Act 936)}

The Act 936 of 2016 has repealed the Local Government Act, 1993 (Act 462) with improved and enhanced provisions for effective decentralization in Ghana. The Act 462 was enacted to establish and regulate the local government system to foster economic growth and development at the local government level. This Act created the Districts and Assemblies to allow for governance at the lower levels. In ensuring health and safety in the construction industry, the Act imposes duties on District Planning Officers and other District Personnel to ensure a proper monitoring and enforcement of health and safety in all operations and at workplace. In fact, the Act further provides that District Planning Authority should make adequate provisions to control construction activities within the 
District. Moreover, they are required by the Act to make proper checks before issuing a building permit for construction.

\subsubsection{Manufacturers/Suppliers' Compliance with Existing Construction Health and Safety (CHS) Related Laws and Regulations}

The Supplier interviewees indicated that the health and safety requirement concerning manufacturing and the supply of materials most complied with is the "supply specification" usually extracted from the contract document. Supply specifications are the detailed description of goods to be manufactured and/or supplied to the client. MS1 pointed out that,

"Manufacturers/ suppliers currently do not operate or comply with any existing Act in the delivery of their work but complies with the supply specifications provided by the contractors or consultants."

The laws regulating the supply of goods In Ghana, according to the Public Procurement Act, 2003 (Act 663) as amended by Public Procurement Amendment Act 2016 (Act 914) of Ghana [30]; Sale of Goods Act, 1962 (Act 137) of Ghana [32] and Hire Purchase Act, 1974 (NRCD 292) of Ghana [33], supply of goods is to meet the provisions made within the laws. These laws establish the relationship between the seller (supplier) and the buyer (purchaser) or hirer. The laws, however, failed to deal with health and safety related issues among the duties of the supplier and purchaser. Suppliers and purchasers are obliged to ensure environmentally sustainable procurement of goods [30]. This duty when obliged shall protect the public from health and safety matters.

\subsubsection{Traditional Authorities and Leaders' Compliance with Existing Construction Health and Safety (CHS) Related Laws and Regulations}

All the interviewees pointed out customary law as the bye law most complied with. Customs are peculiar to communities and often stipulate what is expected of the people in a particular community.

"Customs of our community stipulate the means of preserving our environment, hence the customs and tradition of a community must be complied with by anyone who comes to do business within the community. It is therefore our responsibility to ensure compliance by everyone. The failure to comply with our customary laws constitutes a breach of the custom which is a taboo. As leaders, we often perform traditional rites to clean every taboo" (TL 5).

"It is our responsibility to ensure that the bye laws of the District Assembly within our community is complied with by the contractors to ensure CHS in the community. Most of the workers are our children and we monitor the work to protect them" (TL 2).

According to [34]; [14] customary law is defined as the rules of law which by custom are applicable to particular communities in Ghana. All acceptable customs in any community of Ghana relating to CHS matters are enforceable in Ghana. They may be unique to a particular community. Contractors and project stakeholders are required to familiarize themselves with the customs of the 
project location. Some customs have their roots from ensuring health and safety of the people. For example, a community may prevent activities close to a river. The intention may be to prevent activities that may contaminate the drinking water of the community. It is the responsibility of traditional and community leaders to enforce such custom.

\subsubsection{Regulatory Bodies' Compliance with Existing Construction Health and Safety (CHS) Related Laws and Regulations}

Each Regulatory Body interviewee indicated that CHS is ensured through the law that mandates it to function. There were diverse responses given by the interviewees. The Police officer mentioned the Public Order Act, the Labour Officers mentioned the Labour Act, the Inspectors mentioned the Factories, Offices and Shops Act and Labour Act whilst the Fireman mentioned the Ghana National Fire Service Act and the Fire Regulations. The Environmental Protection Authority official stated the Environmental Protection Act and Public Procurement Authority officer mentioned Public Procurement Act as amended, as the laws related to $\mathrm{CHS}$ which they complied with.

The Policeman coded as RG2 said,

"We only act when a complaint has formally been made to our station. We are not mandated to go around especially to construction sites hunting for accused persons."

It was pointed out that,

"Even though we are required to work closely with the construction firms by having firsthand information about each project, the contractors hardly submit the required information to the office" (RG5 of Labour Department).

The Inspectors of the Factories, Shops and Offices Department coded as RG3 stated that,

"Our focus is more on the factories. We are limited in staff and other logistics to cover the construction industry even though our mandate covers them. We hardly submit report on the construction industry."

It was also stated that,

"New factories submit their feasibility report for assessment, but other commercial and public and private developers do not submit any report for assessment. We however from time-to-time conduct inspections on construction building and engineering projects to assess the environmental impact on the potential users and the public as mandated by the EPA Act'. (RG6)

It was said by RG4 (from PPA) that,

"CHS manual or guidelines within the procurement processes has not been developed. We however believe that throughout the tendering process and contract administration manuals, CHS can be achieved".

Fireman, RG1 stated that,

"Our mandate is to grant fire certificates for public and other commercial buildings. We do not have the mandate to prosecute developers and public institutions who fail to apply for the certificate. We are limited with logistics in the 
core mandate of fighting fire, enforcing the certification of potential and on-going construction activities is a challenge."

Generally, the Regulators comply with the laws and regulations relating to their respective organizations. A little more action on the part of the Regulators, beyond what they currently do, can go a long way to ensure monitoring and enforce compliance with existing laws and regulations in the GCI. Regulators have to be proactive in the execution of their duties under the existing laws and regulations since ineffective enforcement by regulatory institutions results in lack of fear for punitive measures for flouting CHS regulations and laws, and consequently low level of compliance [5]. Regulators require training and education on existing laws and regulations on CHS.

\section{1) Ghana Police Service}

According to the Ghana Police Act, 1970 (Act 350) of Ghana [35] police officers of Ghana Police Service are to assist in the event of fire. Section 33 of Factories, Offices and Shops Act, 1970 (Act 328) of Ghana [36] provides for the Police officer to assist in extinguishing a fire which threatens life or property and for that purpose a police officer may enter a building or part of it and do all other things which the police officer considers necessary to check the spread of the fire. They are also to provide law and order where safety is threatened.

\section{2) Department of Factories Inspectorate}

According to Factories, Offices and Shops Act, 1970 (Act 328) of Ghana [36] the District Inspectors of Department of Factories Inspectorate are to inspect and report any dangerous conditions, practices and premises to a District Court. It also exhorts any inspector, or any person aggrieved by an order of the District Court to appeal to a Justice of the High Court.

\section{3) Environmental Protection Act, 1994 (Act 490)}

The Act 490 also known as the EPA Law is an Act of Parliament which established the Environmental Protection Authority which replaces the previous Environmental Protection Council. The Authority's functions on health and safety include ensuring a proper discharge of waste into the environment and improving the quality of the environment. These functions limit health hazards to a community as a result of certain construction operations. Another health and safety function of the Agency is to ensure that the intensity and volume of noise pollution are controlled (Section $2(\mathrm{~g})$ ). Other functions of the Agency indicated by the Act include ensuring the control of air pollution within the environment of operations, enforcing the carrying out of their duties, enforcing notice to individuals to take the necessary steps to stop or prevent activities which are hazardous to the public health. This part also makes provisions to those who actually qualified to be Environmental Inspectors and their powers to act.

\section{Summary of Findings}

Based on the results of the study the five major sources of construction health and safety (CHS) related laws and regulations most complied with by the stakeholders as shown in Figure 2 are: Bye-Laws, Labour Act, 2003 (Act 651), 


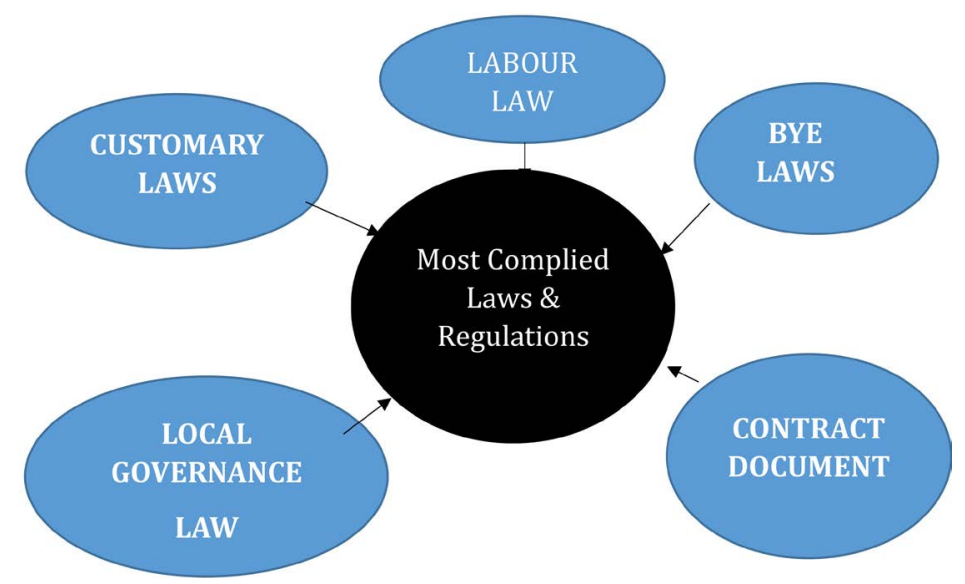

Figure 2. Construction health and safety related laws and regulations most complied with in Ghana.

Contract Document, Local Governance Act, 2016 (Act 936) and Customary Laws.

The study by Osei-Asibey [15] identified that there are more than 25 other laws and regulations by stakeholders relating to CHS [37] [38]. The total laws and regulations that stakeholders in Ghana ought to educate themselves on, to ensure CHS, are therefore more than 37 [15]. Knowledge of Contractors on the laws and regulations relating to health and safety is limited to only six out of the over 37 laws, and much education must be made to improve the knowledge of contractors and other stakeholders. Consultants and suppliers are each limited to only one law out of the over $37 \mathrm{CHS}$ laws relating to their roles. Construction workers, Traditional leaders and officials of the Local Government Agencies have knowledge on only 2 CHS related laws and regulations each. The identification of contract documents as a major regulation complied with by stakeholders agrees with the finding by [5].

\section{Conclusions and Recommendations}

This paper aimed at exploring the extent of compliance by stakeholders with existing legislations and regulations relating to construction health and safety (CHS) in the GCI. A qualitative research approach was adopted for the data collection, using a well-structured interview guide and an in-depth face-to-face interview based on the grounded theory approach. Participants were drawn stakeholders who played important roles in ensuring CHS at the construction site as well as key officers and professionals who are the major stakeholders in the GCI. Content analysis was adopted for the analysis of the qualitative data.

The study showed customary laws, bye laws, Labour Act, 2003 (Act 651), Local Governance Act, 2016 (Act 936) and the contract document as the key existing CHS related legislation and regulations that the stakeholders complied with. The stakeholders also identified the following regulations as having some relation with construction health and safety in the GCI but with low compliance rate: Factories, Shops and Offices Act, 1974 (Act 328), Environmental Protection 
Act, 1994 (Act 490), Fire Precaution (Premises) Regulation, 2003 (L.I. 1724) as Amended by Fire Precautions (Premises) Amendments Regulation, 2016 (L.I. 2249) and Electrical Wiring Regulation, 2011 (L.I. 2008). The study further revealed that not all laws and regulations related to CHS in Ghana are known to the stakeholders.

The study was limited to large construction firms expected to know much about the laws and regulations relating to the construction industry. Further research is recommended on the micro, small and medium construction enterprises to assess their level of knowledge of CHS related laws and regulations. The findings of the research contribute to knowledge of stakeholders' level of knowledge and compliance with existing legislations and regulations related to CHS. The findings underscore the need to ensure monitoring and enforce compliance with existing legislations and regulations in the GCI. The findings further identify areas for stakeholders to focus attention in ensuring good health and safety practices in the GCI. The findings also expose critical training and education needs of stakeholders in the GCI. The findings provide valuable insights on the level of compliance with legislations and regulations related to CHS in Ghana, which may be applicable to other developing countries with similar construction industry. An institution such as Construction Authority is recommended to be set up by Government of Ghana to train, educate, monitor and control stakeholders of the GCI, especially in the area of CHS related laws and regulations. The fragmented laws of Ghana relating to CHS should be put together as one source document by Parliament for easy reference by stakeholders. It is also recommended to include a test on CHS laws and regulations as one of the criteria for the issuance of Consultants' and Contractors' license to operate in Ghana.

\section{Conflicts of Interest}

The authors declare no conflicts of interest regarding the publication of this paper.

\section{References}

[1] International Labour Organization (ILO) (2005) ILO Convention 155. Number of Work-Related Accidents and Illnesses Continues to Increase. ILO/WHO Joint Press, Geneva.

[2] Kheni, N.A., Dainty, A.R.J. and Gibb, A.G.F. (2005) Health and Safety Management Practices of Small Subcontractors. In: Khosrowshahi, F., Ed., 21st Annual ARCOM Conference, 7-9 September 2005, SOAS, University of London. Association of Researchers in Construction Management, Vol. 1, 105-141.

[3] Rowlinson, S. (Ed.) (2004) Construction Safety Management Systems. Routledge, London. https://doi.org/10.4324/9780203493960

[4] Donaghy, R. (2009) One Death Is Too Many: Inquiry into the Underlying Causes of Construction Fatal Accidents, Rita Donaghy's Report to the Secretary of State for Work and Pensions. Cm 7657, Derecho International, Office of Public Sector Information, Information Policy Team, Kew, Richmond, Surrey TW9 4DU.

[5] Eyiah, A.K., Kheni, N.A. and Quartey, P.D. (2019) An Assessment of Occupational 
Health and Safety Regulations in Ghana: A Study of the Construction Industry. Journal of Building Construction and Planning Research, 7, 11-31. https://doi.org/10.4236/jbcpr.2019.72002

[6] Osei-Asibey, D., Ayarkwa, J., Adinyira, E., Acheampong, A. and Amoah, P. (2021) Roles and Responsibilities of Stakeholders towards Ensuring Health and Safety at Construction Site. Journal of Building Construction and Planning Research, 9, 90-114. https://doi.org/10.1680/jmapl.16.00019

[7] Salinero Pampliega Project Management (2013) Stakeholder Management in the Construction Sector.

[8] Donkoh, D. and Aboagye-Nimo, E. (2016) Stakeholders' Role in Improving Ghana's Construction Safety. Proceedings of the Institution of Civil Engineers, 170, 68-76. https://doi.org/10.1680/jmapl.16.00019

[9] Banfield, P. and Kay, R. (2012) Introduction to Human Resource Management. Oxford University Press, Oxford.

[10] Laryea, S. and Sarfo, M. (2010) Health and Safety on Construction Sites in Ghana. The Construction, Building and Real Estate Research Conference of the Royal Institution of Chartered Surveyors, Paris, France, 2-3 September 2010. http://centaur.reading.ac.uk/16289/

[11] Dadzie, J. (2013) Perspectives of Consultants on Health and Safety Provisions in the Labour Act: A Study into Theory and Practicals. Engineering Management Research, 2, 34-42. https://doi.org/10.5539/emr.v2n1p34

[12] Kheni, N.A., Gibb, A.G.F. and Dainty, A.R.J. (2010) Health and Safety Management within Small- and Medium-Sized Enterprises (SMEs) in Developing Countries: Study of Contextual Influences. Journal of Construction Engineering and Management, 136, 1104-1105. https://doi.org/10.1061/(ASCE)CO.1943-7862.0000218

[13] Kheni, N.A. (2008) Impact of Health and Safety Management on Safety Performance of Small and Medium-Sized Construction Businesses in Ghana, unpublished PhD Thesis, Department of Civil Engineering, Loughborough University, Loughborough.

[14] 1992 Constitution of Republic of Ghana. Ghana Publishing Co., Accra.

[15] Osei-Asibey, D. (2020) Development of Regulatory Framework for Implementation of Construction Health and Safety Practices at Construction Site. Submitted PhD Dissertation, Graduate School, Kwame Nkrumah University of Science and Technology, Kumasi.

[16] Labour Act, 2003 (Act 651), Ghana Publishing Co., Accra, Republic of Ghana.

[17] Leamon, T.B. (2001) The Future of Occupational Safety and Health. International Journal of Occupational Safety and Ergonomics, 7, 403-408.

https://doi.org/10.1080/10803548.2001.11076510

[18] Jaselskis, E.J, Anderson, S.D. and Russell, J.S. (1996) Strategies for Achieving Excellence in Construction Safety Performance. Journal of Construction Engineering and Management, 122, 245-255. https://doi.org/10.1061/(ASCE)0733-9364(1996)122:1(61)

[19] Gallagher, C. (1997) Occupational Health and Safety Management Systems: An Analysis of System Types and Effectiveness. Monash University, National Key Centre in Industrial Relations, Melbourne, Victoria, Australia.

[20] Gad, S. and Collins, A.M. (2002) Safety Culture: A Review of the Literature. Health and Safety Laboratory, London.

[21] Hinze, J. and Gambates, J. (2003) Factors Influencing Safety Performance of Spe- 
cialty Contractors. Journal of Construction Engineering and Management, 129, 159-164. https://doi.org/10.1061/(ASCE)0733-9364(2003)129:2(159)

[22] Wright, M.S. (1998) Factors Motivating Proactive Health and Safety Management. Contract Research Report No. 179/1998, Health and Safety Executive Books.

[23] Fung, I.W.H., Tam, V.W.Y., Sing, C.P., Tang, K.K.W. and Ogunlana, S.O. (2016) Psychological Climate in Occupational Safety and Health: The Safety Awareness of Construction Workers in South China. International Journal of Construction Management, 16, 315-325. https://doi.org/10.1080/15623599.2016.1146114

[24] Baldock, R., Vickers, I., Smallbone, D. and James, P. (2005) Health and Safety in Small Firms: What Are the Main Influences on the Adoption of Improvement Measures? MUBS Discussion Papers, Makerere University Business School, Kampala, Uganda.

[25] Flick, U. (2006) An Introduction to Qualitative Research. Sage, London.

[26] Gay, D.A., Morgan, F.D., Vichabian, Y., Sogade, J.A., Reppert, P. and Wharton, A.E. (2006) Investigations of Andesitic Volcanic Debris Terrains: Part 2-Geotechnical. Geophysics, 71, B9-B15. https://doi.org/10.1190/1.2159046

[27] Saunders, M., Lewis, P. and Thornhill, A. (2009) Research Methods for Business Students. Pearson Education, Prentice Hall, London, New York, Boston.

[28] Sandelowski, M. and Barroso, J. (2007) Handbook for Synthesizing Qualitative Research. Springer Publishing Company, New York.

[29] National Building Regulation, 1996 (L.I. 1630), Republic of Ghana, Ghana Publishing Company, Assembly Press, 1996.

[30] Public Procurement Act, 2003 (Act 663) as Amended by Public Procurement Amendment Act, 2016 (Act 914) Republic of Ghana, Ghana Publishing Company, Assembly Press, 2004/2016.

[31] Workmen's Compensation Act, 1987 (PNDCL 187), Republic of Ghana, Ghana Publishing Company, Assembly Press, 1987.

[32] Sale of Goods Act, 1962 (Act 137) Republic of Ghana, Ghana Publishing Corporation, Assembly Press, 1987.

[33] Hire Purchase Act, 1974 (NRCD 292), Republic of Ghana, Ghana Publishing Corporation, Assembly Press, 1974.

[34] Interpretation Act, 2009 (Act 752) Republic of Ghana, Ghana Publishing Company, Assembly Press, 2009.

[35] Ghana Police Act, 1970 (Act 350) Republic of Ghana, Ghana Publishing Corporation, Assembly Press, 1970.

[36] Factories, Offices and Shops Act, 1970 (Act 328) Republic of Ghana, Ghana Publishing Corporation, Assembly Press, 1970.

[37] Crabbe, V.C.R.A.C. (2005) Laws of Ghana: Volumes 1-7. LexisNexis Butterworths (Pty) Ltd. S.A, Accra, Accra.

[38] Ghana Publishing Company Ltd. (2020) List of Publications. Ghana Publishing Company, Assembly Press, Accra. 